Research Paper

\title{
The capacity of greening roof to reduce stormwater runoff and pollution
}

\author{
Qianqian Zhang $^{\mathrm{a}}$, Liping Miao ${ }^{\mathrm{b}}$, Xiaoke Wang ${ }^{\mathrm{c}, *}$, Dandan Liu ${ }^{\mathrm{a}}$, Liang Zhu ${ }^{\mathrm{a}}$, Bing Zhou ${ }^{\mathrm{a}}$, \\ Jichao Sun ${ }^{a}$, Jingtao Liu ${ }^{\mathrm{a}}$ \\ a Institute of Hydrogeology and Environmental Geology, Chinese Academy of Geological Science, Shijiazhuang 050061, China \\ ${ }^{\mathrm{b}}$ Agriculture Regional Planning Office of Hebei Province, Shijiazhuang 050000, China \\ ' State Key Laboratory of Urban and Regional Ecology, Research Center for Eco-Environmental Sciences, Chinese Academy of Sciences, Beijing 100085, China
}

\section{H I G H L I G H T S}

- The green roof could effective reduce stormwater runoff.

- A key factor affecting runoff retention was the depth of rainfall.

- The green roof acted as a sink of $\mathrm{NH}_{4}{ }^{+}-\mathrm{N}$ and could neutralize the $\mathrm{pH}$ of rainfall.

- The water quality of runoff was seriously affected by the soil substrate of the green roof.

- The green roof was effective in abating the loading of most pollutants.

\section{A R T I C L E I N F O}

\section{Article history:}

Received 31 October 2014

Received in revised form 28 August 2015

Accepted 30 August 2015

Available online 22 October 2015

\section{Keywords:}

Green roof

Runoff retention

Water quality

Pollutants load

Soil substrate

\begin{abstract}
A B S T R A C T
To examine the stormwater retention capacity and runoff water quality of a green roof in Chongqing, China, 19 rainfall event samples of runoff and dry and wet deposition were measured. The results showed that the green roof effectively retained stormwater runoff, with retention ranging from $35.5 \%$ to $100 \%$, with an average retention of $77.2 \%$. The annual runoff retention of the green roof showed that the retention volume and rate reached $758.7 \mathrm{~mm}$ and $68.0 \%$, respectively. When we compared the stromwater quality among the green roof, asphalt (control) roof, dry and wet deposition and rainfall samples, found that the green roof reduced the concentration of TSS, and could neutralize the $\mathrm{pH}$ of rainfall; however, it increased the concentrations of TN, $\mathrm{NH}_{4}{ }^{+}-\mathrm{N}, \mathrm{NO}_{3}{ }^{-}-\mathrm{N}, \mathrm{TOC}, \mathrm{COD}, \mathrm{BOD} 5, \mathrm{~F}^{-}, \mathrm{Cl}^{-}, \mathrm{SO}_{4}{ }^{2-}, \mathrm{K}^{+}, \mathrm{Ca}^{2+}, \mathrm{Si}^{4+}, \mathrm{DPb}, \mathrm{DAl}, \mathrm{DMn}$, and DFe. When we compared the pollutant loads from the green roof and rainfall samples, found that the green roof was a sink for $\mathrm{NH}_{4}^{+}-\mathrm{N}$, but was sources of $\mathrm{NO}_{3}{ }^{-}-\mathrm{N}, \mathrm{K}^{+}, \mathrm{Si}^{4+}, \mathrm{Ca}^{2+}$, TOC and DAl. Overall, the green roof was effective in reducing stormwater runoff, neutralizing acid deposition and abating the loading of most pollutants; however, the water quality of runoff was seriously affected by the soil substrate. Therefore, we suggest that green roofs need to be constructed of suitable materials in order to avoid deterioration of runoff water quality.
\end{abstract}

(c) 2015 Elsevier B.V. All rights reserved.

\section{Introduction}

A "Green" roofs are roofs whose construction typically consists of a root barrier, drainage material layer, filter fabric, growing media and vegetation (Berndtsson, 2010; Carter \& Rasmussen, 2006). In recent years, green roofs have become a trend in urban

\footnotetext{
* Corresponding author.

E-mail addresses: z_qqian@163.com (Q.Zhang),156494841@qq.com (L. Miao), wangxk@rcees.ac.cn (X. Wang), ldd5104206@163.com (D. Liu), 444751823@qq.com (L.Zhu), 371934358@qq.com (B.Zhou), 974375676@qq.com (J.Sun),728881944@qq.com (J. Liu).
}

architecture and are widely used in such countries as Germany, Sweden, USA, Japan and Singapore. Green roofs benefits (Berardi, GhaffarianHoseini, \& GhaffarianHoseini, 2014) include their ability to retain and detain roof stormwater runoff(Berndtsson, Bengtsson, \& Jinno, 2008; Lee, Moon, Kim, Kim, \& Han, 2013; Vijayaraghavan, Joshi, \& Balasubramanian, 2012), reduce urban heat islands (Fang, 2008; Wong, Chen, Ong, \& Sia, 2003), improve air quality (Currie \& Bass, 2008), and provide wildlife habitats (Dunnett, Nagase, \& Hallam, 2008; Gedge \& Kadas, 2005), in addition to their esthetic value.

One important aspect often overlooked in previous studies is the quality of the runoff water from green roofs (Chen, 2013; Vijayaraghavan et al., 2012). Green roofs may reduce the pollution 
of stormwater runoff by filtering and absorbing pollutants, as the roofs are covered with soil and vegetation. Berndtsson, Emilsson, and Bengtsson (2006) in Malmo and Lund, Sweden, found that different types of green roofs act as sinks for nitrate nitrogen $\left(\mathrm{NO}_{3}{ }^{-}-\mathrm{N}\right)$ and also reduce levels of ammonium nitrogen $\left(\mathrm{NH}_{4}{ }^{+}-\mathrm{N}\right)$ and total nitrogen (TN). However, green roofs can potentially contribute to pollutants released from soil, plants and fertilizers. Vijayaraghavan and Raja (2015) revealed that green roofs acted as sinks for various metal ions and generated better runoff during metal-spiked artificial rain events. Moran, Hunt, and Jennings (2004) found that compost in the substrate layer could cause high concentrations of nitrogen and phosphorus in the runoff from green roofs in North Carolina, USA.

All previous published studies show the ability of green roofs to retain and detain storm water. Summarizing the studies in German from 1987 to 2003, Mentens, Raes, and Hermy (2006) concluded that intensive green roofs reduce annual runoff by $65-85 \%$ of annual precipitation (100\%), while for extensive roofs, the corresponding values were 27-81\%. Gregoire and Clausen (2011) summarized part of the existing literature through a Metaanalysis, and found that extensive green roofs constructed to reduce stormwater runoff are able to intercept, retain, and evapotranspire $34-69 \%$ of precipitation, with an average retention rate of $56 \%$.

The retention capacity of green roofs is affected by many factors. VanWoert et al. (2005) and Getter, Rowe, and Andresen (2007) reported that the retention values of green roofs decrease as roof slopes increase. Stovin et al. (2007) and Lee, Lee, and Han (2015) found that increasing the number of antecedent dry days can help to improve water retention capacity and delay occurrence time. Villarreal and Bengtsson (2005) recorded an inverse relationship between rainfall intensity and the water retention capacity of the studied green roofs.

The main objective of the current study was to thoroughly examine the effects of green roofs on the quality and quantity of rainfall runoff, using both the local soil and a commercial substrate as roof components. The specific objectives were to: (1) investigate the runoff retention capacity of green roofs; (2) determine the relationships between runoff retention capacity and storm characteristics; and (3) assess whether green roofs behave as sinks or sources of chemical substances in the runoff in terms of the pollutants load of the runoff.

\section{Materials and methods}

\subsection{Study site}

Roof rainwater runoff was monitored at a newly developed site surrounded by a school, road and building land in Yubei district, Chongqing, China. The area has a subtropical monsoon climate, with a mean annual temperature of $17.5-18.7^{\circ} \mathrm{C}$, and in year 2006 to 2011 annual rainfall ranged from 1100 to $1300 \mathrm{~mm}$. Most of the precipitation occurs during the period between April and July, the highest temperature occurring during the July and September (Fig. 1).

\subsection{The structure of the green roof}

The studied "green" (vegetated) roof $(1.0 \mathrm{~m}$ wide $\times 1.0 \mathrm{~m}$ long) and reference (asphalt) roof ( $1.5 \mathrm{~m}$ wide $\times 1.5 \mathrm{~m}$ long) were constructed in August 2010, and laid in parallel on the roof of a school. The two roof types were installed in accordance with local construction material standards and two duplicate pilot-scale roofs were arranged in an alternating sequence. The pilot-scale roofs were positioned $1 \mathrm{~m}$ above the school building roof, and had a $40 \mathrm{~cm}$ fence with potable-quality polyvinyl chloride (PVC) lining to prevent rainwater splashing out from the roof.

The green roof assembly consisted of four layers, the uppermost being a vegetation layer comprising of a thick $(15 \mathrm{~cm})$ growing substrate and plants. The second layer was a filter layer in the form of a non-woven geotextile, which prevented small particles from being washed from the substrate layer into the drainage layer or out of the system. The third layer was a drainage layer in the form of a large drainage board (length $\times$ width $\times$ height: $33.3 \times 33.3 \times 2.0 \mathrm{~cm}$ ). The last layer was an additional waterproof layer, comprising a modified asphalt felt paved onto the original concrete roof.

The substrate composition was based on roof greening material available in China (BLS, 2005) and information from Gregoire and Clausen (2011). In addition, considering the growth environment of plant and bearing capacity of the roof, a mixture of lightweight materials was used as the substrate (the volume ratio of each matrix: peat soil: vermiculite: perlite: sawdust was 4:3:2:1). Buddhanail (Sedum lineare Thunb) was selected for the present study because of its ability to survive in conditions of low nutrients, drought and extreme temperature, and was planted in the

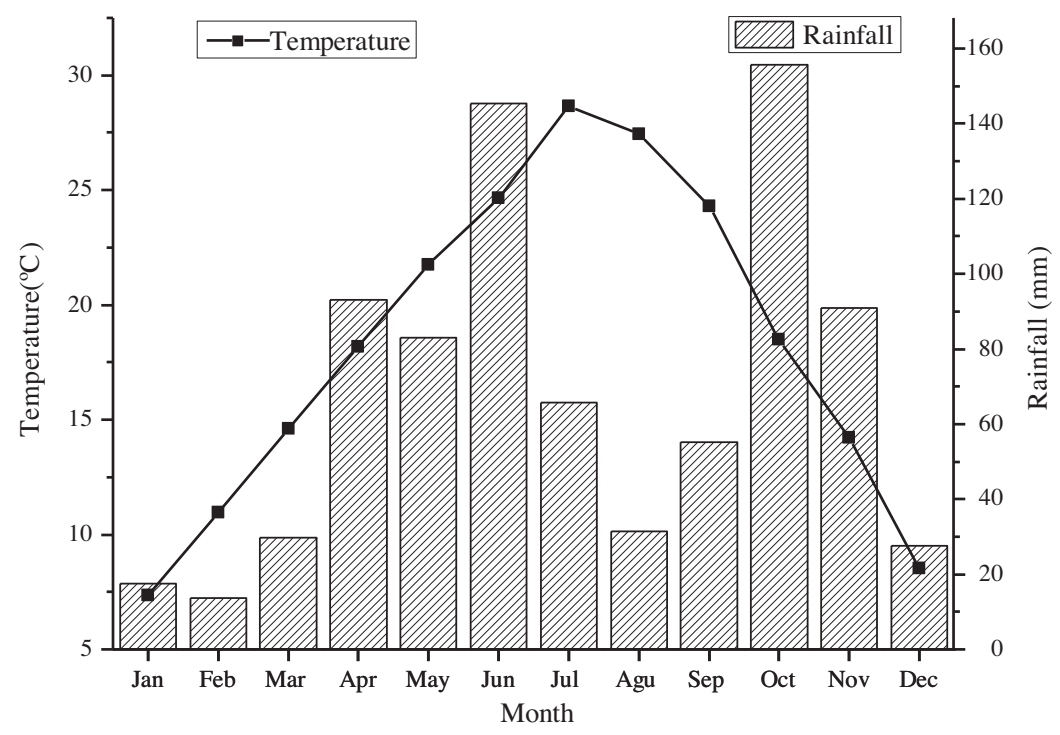

Fig. 1. Temporal variations of rainfall and air temperature for 2011. 
Table 1

The rainfall characteristics for investigated rain events.

\begin{tabular}{|c|c|c|c|c|c|c|}
\hline Monitored events & $\mathrm{P}(\mathrm{mm})$ & $\operatorname{ADWP}(\mathrm{d})$ & $\operatorname{ARF}(\mathrm{mm})$ & RD range $(\mathrm{h})$ & ARI range (mm/Min) & MRI range (mm/Min) \\
\hline $2011-5-30$ & 13.5 & 8.46 & 32.1 & 17.5 & 0.0121 & 0.06 \\
\hline $2011-6-5$ & 8.7 & 4.96 & 12.7 & 5.9 & 0.0235 & 0.08 \\
\hline 2011-6-14 & 29.2 & 1.79 & 1.4 & 20.8 & 0.0224 & 0.52 \\
\hline 2011-6-17 & 84.8 & 2.83 & 27.9 & 28.4 & 0.0499 & 1.76 \\
\hline $2011-6-22$ & 7.8 & 4.00 & 84.8 & 15.6 & 0.0079 & 0.1 \\
\hline 2011-7-11 & 12.4 & 17.96 & 7.4 & 5.0 & 0.0413 & 0.18 \\
\hline $2011-7-13$ & 7.5 & 1.50 & 12.4 & 9.8 & 0.012 & 0.04 \\
\hline 2011-7-19 & 3.3 & 4.08 & 9.5 & 12.2 & 0.005 & 0.01 \\
\hline $2011-7-22$ & 9.5 & 3.00 & 1.6 & 17.3 & 0.0092 & 0.1 \\
\hline $2011-8-2$ & 4.8 & 4.38 & 3.3 & 17.6 & 0.004 & 0.02 \\
\hline $2011-8-4$ & 25.1 & 1.71 & 4.2 & 15.0 & 0.0279 & 0.26 \\
\hline 2011-9-10 & 26.5 & 33.92 & 25.1 & 37.9 & 0.0117 & 0.12 \\
\hline 2011-9-19 & 9.9 & 9.17 & 26.5 & 12.3 & 0.0106 & 0.1 \\
\hline $2011-9-29$ & 4.6 & 6.29 & 3.1 & 113.0 & 0.0007 & 0.04 \\
\hline 2011-10-2 & 68.4 & 1.79 & 4.6 & 41.0 & 0.0278 & 0.16 \\
\hline 2011-10-11 & 33.7 & 0.79 & 1.5 & 32.6 & 0.0172 & 0.9 \\
\hline 2011-10-12 & 20.4 & 0.46 & 33.7 & 12.4 & 0.0275 & 0.74 \\
\hline 2011-10-15 & 2.5 & 1.21 & 20.4 & 2.5 & 0.017 & 0.02 \\
\hline 2011-11-7 & 3.7 & 1.25 & 23.7 & 27.0 & 0.002 & 0.04 \\
\hline
\end{tabular}

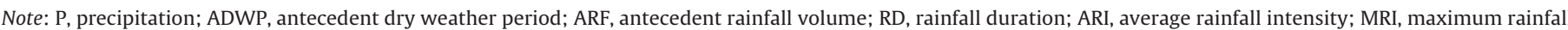
intensity.

substrate at a density of 162 plugs $/ \mathrm{m}^{2}$ (plant spacing is $4-6 \mathrm{~cm}$ and line spacing $8-10 \mathrm{~cm}$ ).

\subsection{Rainwater sampling devices}

\subsubsection{Roof runoff sampling}

A sampling insert (potable-quality PVC pipe with internal diameter $6 \mathrm{~cm}$ ) was placed in the gutters of the pilot-scale roof and at the PVC pipe outlet, connected to a drainpipe (the drainpipe material was plastic), which was in turn connected to a rainwater sampler (the sampler material was polyethylene).

\subsubsection{Dry and wet deposition (bulk depositions) and wet deposition (rainfall) sampling}

Dry and wet deposition and wet deposition were collected using a plastic box $(35 \times 25 \times 25 \mathrm{~cm})$ within one hour after each rainfall stopped, then the sampling boxes were rinsed with deionized water and replaced on the roof before the next rainfall. The sampling boxes were covered in dry days and were opened before rainfall for wet deposition, while the sampling boxes were always opened for the dry and wet deposition.

\subsection{Sampling and analyses}

\subsubsection{Sample collection}

Samplings of roof runoff and deposition were carried out from May 2011 to November 2011. The rainfall characteristics for the investigated rain events are shown in Table 1 . The sampling was performed using a plastic cup. Prior to sampling, the plastic cup was rinsed three times with pure water and twice with the uniformly mixed roof runoff harvested in the sampler. Subsequently, three water samples were collected from each roof and were stored in $1 \mathrm{~L}$ polyethylene bottles in a container with ice packs and transported to the laboratory immediately. Water retention were measured for 19 rain events in 2011. Water chemical analyses were carried out for 12 rain events in 2011 for the green roof, due to the total retention of all rainfall during 7 events over our monitoring period. Samples of green roof runoff, control roof runoff, dry and wet deposition, and rainfall were analyzed for 21 water-quality parameters.

\subsubsection{Chemical analysis}

After the composite sample obtained, the runoff and deposition sampler was emptied, then samples were immediately prepared for analyses. The $\mathrm{pH}$ was analyzed using a portable meter (SensION ${ }^{\mathrm{TM}}$ 156; Hach, Loveland, CO, USA). The major dissolved (D) metals $\mathrm{Cu}, \mathrm{Pb}, \mathrm{Zn}, \mathrm{Fe}, \mathrm{Mn}$ and $\mathrm{Al}$ were analyzed by inductively coupled plasma mass spectroscope (ICP-MS 7500a; Agilent Technologies Inc., Wilmington, DE, USA). Cations (potassium $\left[\mathrm{K}^{+}\right]$, calcium $\left[\mathrm{Ca}^{2+}\right]$ and silicate $\left[\mathrm{Si}^{4+}\right]$ ) were measured by inductively coupled plasma optical emission spectrometer (ICP-OES) (Prodigy; Teledyne Leemans Labs, Hudson, NH, USA); and anions (fluoride $\left[\mathrm{F}^{-}\right]$, chloride $\left[\mathrm{Cl}^{-}\right]$and sulphate $\left[\mathrm{SO}_{4}{ }^{2-}\right]$ ) were measured by ion chromatograph (ICS-1000; Dionex Corp., Sunnyvale, CA, USA). In accordance with the National Standard Method of China (GB38382002a), biochemical oxygen demand after 5 days $\left(B_{5}\right)$ was analyzed using a dilution and seeding method (850A+; Thermo Scientific Orion, Beverley, MA, USA); Chemical oxygen demand (COD) was analyzed using the rapid digestion and spectrophotometric method; TN was measured using the alkaline potassium persulfate digestion and UV spectrophotometric method; $\mathrm{NH}_{4}{ }^{+}-\mathrm{N}$ was measured using Nessler's reagent spectrophotometric method; $\mathrm{NO}_{3}{ }^{-} \mathrm{N}$ was measured using the phenol disulfonic acid spectrophotometric method; total phosphorus (TP) was measured using the persulfate digestion spectrophotometric method; total suspended solids (TSS) were measured using the filtering, drying, and weighing method; total organic carbon (TOC) was measured using a total carbon analyzer (Liquic TOC II; Elementar Analysensysteme GmbH, Hanau, Germany). The quality assurance and quality control (QA/QC) for water sampling and analysis strictly followed the guidelines set by $\operatorname{SEPAC}(2002 a, b)$.

\subsubsection{Data analysis}

2.4.3.1. Runoff retention rate. Runoff retention rate from greenroof runoff was calculated as:

$\mathrm{RR}=\frac{(\mathrm{RV}-V)}{\mathrm{RV}} \times 100 \%$

$\mathrm{RV}=R \times A$

Where RR is the runoff retention rate (\%); RV refers to the rainfall volume actually received by greenroof $(\mathrm{L}) ; V$ is the runoff depth of greenroof $(\mathrm{L}) ; R$ is the rainfall volume $(\mathrm{mm}) ; A$ is the area of greenroof $\left(\mathrm{m}^{2}\right)$.

2.4.3.2. Annual runoff retention rate. The rainfall data from 2006 to 2011 representative of the monitored site was obtained from the Chongqing meteorological bureau (station $4.3 \mathrm{~km}$ from the 
Table 2

Data summary for precipitation (P), green roof (GR), and asphalt roof (AR) hydrologic behavior.

\begin{tabular}{|c|c|c|c|c|c|c|c|}
\hline \multirow[t]{2}{*}{ Monitored events } & \multicolumn{3}{|c|}{ Rainfall volume (mm) } & \multicolumn{2}{|c|}{ Retention volume (mm) } & \multicolumn{2}{|c|}{ Retention rate (\%) } \\
\hline & $\mathrm{P}$ & AR runoff & GR runoff & AR & GR & AR & GR \\
\hline 2011-5-30 & 13.5 & 13.38 & 5.10 & 0.12 & 8.40 & 0.91 & 62.2 \\
\hline 2011-6-5 & 8.7 & 8.44 & 0.00 & 0.26 & 8.70 & 2.94 & 100.0 \\
\hline 2011-6-14 & 29.2 & 29.02 & 8.20 & 0.18 & 21.00 & 0.61 & 71.9 \\
\hline 2011-6-17 & 84.8 & 84.20 & 49.20 & 0.60 & 35.60 & 0.71 & 42.0 \\
\hline $2011-6-22$ & 7.8 & 7.60 & 0.00 & 0.20 & 7.80 & 2.56 & 100.0 \\
\hline 2011-7-11 & 12.4 & 10.49 & 2.15 & 1.91 & 10.25 & 15.41 & 82.7 \\
\hline 2011-7-13 & 7.5 & 7.38 & 2.30 & 0.12 & 5.20 & 1.63 & 69.3 \\
\hline 2011-7-19 & 3.3 & 3.12 & 0.00 & 0.18 & 3.30 & 5.43 & 100.0 \\
\hline $2011-7-22$ & 9.5 & 9.47 & 0.00 & 0.03 & 9.50 & 0.35 & 100.0 \\
\hline $2011-8-2$ & 4.8 & 4.67 & 0.00 & 0.13 & 4.80 & 2.78 & 100.0 \\
\hline 2011-8-4 & 25.1 & 25.02 & 9.65 & 0.08 & 15.45 & 0.31 & 61.6 \\
\hline 2011-9-10 & 26.5 & 26.21 & 5.67 & 0.29 & 20.83 & 1.08 & 78.6 \\
\hline 2011-9-19 & 9.9 & 9.78 & 1.50 & 0.12 & 8.40 & 1.23 & 84.9 \\
\hline 2011-9-29 & 4.6 & 3.73 & 0.00 & 0.87 & 4.60 & 18.84 & 100.0 \\
\hline $2011-10-2$ & 68.4 & 66.42 & 44.00 & 1.98 & 24.40 & 2.90 & 35.7 \\
\hline 2011-10-11 & 33.7 & 33.56 & 14.30 & 0.14 & 19.40 & 0.43 & 57.6 \\
\hline 2011-10-12 & 20.4 & 19.91 & 13.15 & 0.49 & 7.25 & 2.40 & 35.5 \\
\hline 2011-10-15 & 2.5 & 2.33 & 0.00 & 0.17 & 2.50 & 6.97 & 100.0 \\
\hline 2011-11-7 & 3.7 & 3.60 & 0.58 & 0.10 & 3.13 & 2.70 & 84.5 \\
\hline
\end{tabular}

experimental site). Rainfall types and precipitation were statistically analyzed during the period 2006-2010 (Table 3). The results of the green roof runoff retention at different rainfall intensities were used to calculate the annual runoff retention rates for the green roof. During our study, the retention depth was $>2 \mathrm{~mm}$ for all monitored rainfall events, therefore, it was assumed that there was full retention of precipitation in the range $0.1-1.0 \mathrm{~mm}$.

2.4.3.3. Pollutant loading. Pollutant load from greenroof runoff was calculated as:

$\mathrm{PL}=V \times \frac{\mathrm{EMCS}}{A}$

Where PL is the pollutant loading $\left(\mathrm{mg} / \mathrm{m}^{2}\right) ; V$ is the runoff volume from green roof $(\mathrm{L})$; $A$ is the area of greenroof $\left(\mathrm{m}^{2}\right)$; EMCs are the mean concentrations of the monitoring rainfall events $(\mathrm{mg} / \mathrm{L})$.

\subsubsection{Multivariate data analysis}

The differences in water quality for the green roof, asphalt roof, dry and wet deposition, and rainfall samples were evaluated using the nonparametric Kruskal-Wallis test and the nonparametric Mann-Whitney $U$-test, as the data failed to meet the assumption of normality for parametric statistical analyses (Sazakli, Alexopoulos, \& Leotsinidis, 2007). The degree of association between water retention capacity and rainfall depth were determined by using regression analysis. The Kruskal-Wallis test and Mann-Whitney $U$-test were performed using SPSS software (version 19.0; SPSS Inc., Chicago, IL, USA). The regression analysis was performed using OriginPro (version 8.6, OriginLab Corp., Northampton, MA, USA).

\section{Results}

\subsection{Green roof runoff retention}

\subsubsection{Rainfall event retention of the green roof}

On the asphalt (control) roof, the stormwater retention volume ranged from 0.03 to $1.98 \mathrm{~mm}$, with an average retention volume of $0.42 \mathrm{~mm}$, and the retention rate ranged from 0.31 to $18.84 \%$, with an average retention rate of $3.69 \%$ (Table 2). On the green roof, the stormwater retention volume ranged from 2.50 to $35.60 \mathrm{~mm}$, with an average retention volume of $11.61 \mathrm{~mm}$, and the retention rate ranged from 35.5 to $100 \%$, with an average retention rate of $77.2 \%$ (Table 2).

\subsubsection{Monthly runoff retention of the green roof}

The monthly variation in the green roof runoff retention from May to October of 2011 showed that the highest retention rates were occurred in July and September, followed by August, May, and the lowest retention rates were occurred in June and October (Fig. 2).

\subsubsection{Annual runoff retention of the green roof}

Annual runoff retention volume and the retention rates of the green roof reached $758.7 \mathrm{~mm}$ and $68.0 \%$, respectively (Table 3 ).

\subsection{Quality of roof runoff water}

\subsection{1. $p H$ and TSS}

Average $\mathrm{pH}$ was significantly higher for the asphalt roof runoff samples ( $\mathrm{pH} 7.35$ ) than for the green roof runoff (6.84), dry and wet deposition (5.98), and rainwater (5.61) samples (Table 4), probably due to the acid rain dissolving alkaline substances on the asphalt roof. There were no significant differences in average $\mathrm{pH}$ concentrations between the green roof runoff, dry and wet deposition, and rainwater samples. The mean $\mathrm{pH}$ of the dry and wet deposition and rainwater beyond the standard range of 6.0-9.0 (GB3838-2002, $2002 b$ ) for surface water. However, the average TSS concentration of the green roof runoff ( $20.42 \mathrm{mg} / \mathrm{L})$ was significantly lower than that of the asphalt roof runoff $(67.04 \mathrm{mg} / \mathrm{L})$ and was also lower than that of the dry and wet deposition $(36.53 \mathrm{mg} / \mathrm{L}$ ) samples (Table 4).

\subsubsection{Nutrients and organic related parameters}

The average TP concentration of the rainwater $(0.035 \mathrm{mg} / \mathrm{L})$ samples was significantly lower than that of the green roof runoff $(0.113 \mathrm{mg} / \mathrm{L})$, asphalt roof runoff $(0.091 \mathrm{mg} / \mathrm{L})$ and dry and wet

Table 3

Data summary for the mean annual rainfall types (RT), rainfall days (RD), precipitation (P) and green roof runoff retention rates in 2006-2010 years.

\begin{tabular}{lrrrr}
\hline RT & RD (days/year) & $\mathrm{P}(\mathrm{mm})$ & \multicolumn{2}{l}{ Runoff retention } \\
\cline { 4 - 5 } & & & $\mathrm{RA}(\%)$ & $\mathrm{RV}(\mathrm{mm})$ \\
\hline $0.1-1.0$ & 56 & 22.0 & 100.0 & 22.0 \\
$1.0-10$ & 69 & 280.2 & 93.9 & 263.1 \\
$10-24.9$ & 21 & 294.3 & 72.4 & 213.1 \\
$25-49.9$ & 8 & 232.6 & 67.4 & 156.8 \\
$>50$ & 3 & 267.4 & 38.8 & 103.8 \\
Total & 157 & 1116.5 & 68.0 & 758.7 \\
\hline
\end{tabular}

Note: RA, retention rates; $\mathrm{RV}$, retention volume. 


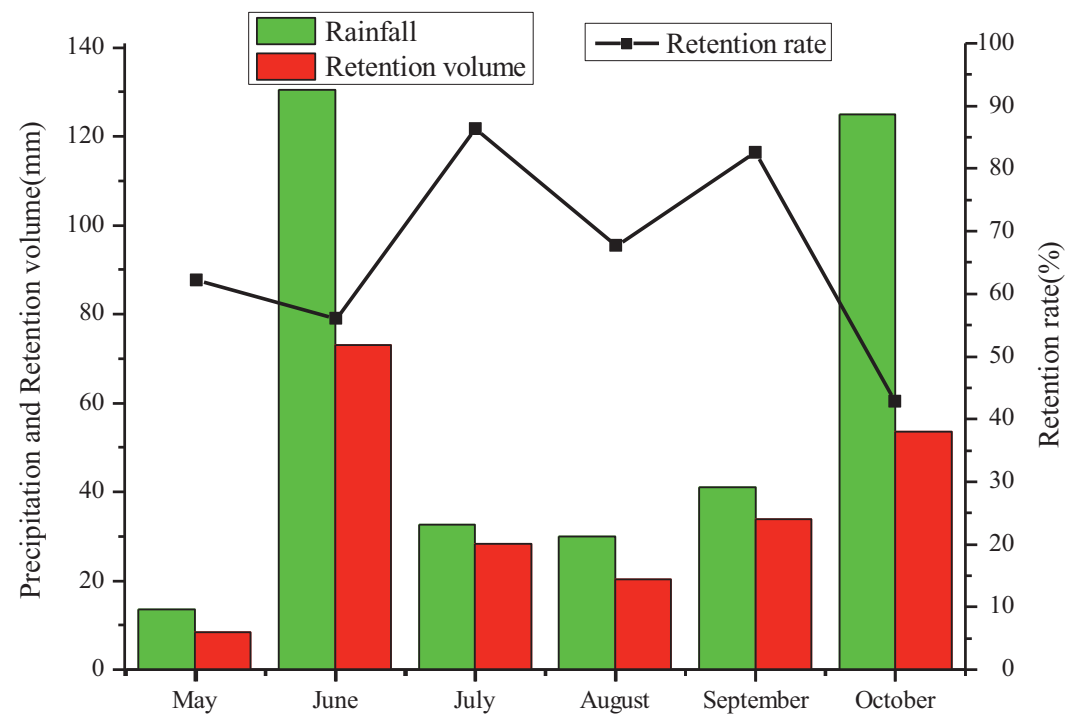

Fig. 2. The monthly variation of rainfall, and green roof retention volume and rate from May to October 2011.

deposition $(0.076 \mathrm{mg} / \mathrm{L})$ samples (Table 4$)$, and there were no significant differences in average TP concentrations between the green roof runoff, asphalt roof runoff, and dry and wet deposition samples. However, the average concentrations of $\mathrm{TN}, \mathrm{NH}_{4}{ }^{+}-\mathrm{N}, \mathrm{NO}_{3}{ }^{-}-\mathrm{N}, \mathrm{TOC}$, $\mathrm{COD}$, and $\mathrm{BOD}_{5}$ were significantly higher in the green roof runoff samples than in the asphalt roof runoff, dry and wet deposition and rainwater samples (Table 4 ).

\subsubsection{Ions and metals}

Average $\mathrm{F}^{-}, \mathrm{Cl}^{-}, \mathrm{SO}_{4}{ }^{2-}, \mathrm{K}^{+}, \mathrm{Ca}^{2+}$, and $\mathrm{Si}^{4+}$ concentrations of the green roof runoff samples were significantly higher than those of the asphalt roof runoff, dry and wet deposition and rainwater samples (Table 4). There were no significant differences in average DCu and DZn concentrations between the green roof runoff, asphalt roof runoff, dry and wet deposition and rainwater samples. However, the average DPb, DAl, DMn, and DFe concentrations in our green roof runoff samples were also significantly higher than those of the asphalt roof runoff, dry and wet deposition and rainwater samples (Table 4).

\subsection{Roof runoff and deposition pollutant load}

Average pollutant load of $\mathrm{NH}_{4}{ }^{+}-\mathrm{N}\left(27.16 \mathrm{mg} / \mathrm{m}^{2}\right)$ in the green roof runoff was significantly lower than for that in asphalt roof runoff $\left(42.23 \mathrm{mg} / \mathrm{m}^{2}\right)$, dry and wet deposition $\left(48.57 \mathrm{mg} / \mathrm{m}^{2}\right)$ and rainwater $\left(49.54 \mathrm{mg} / \mathrm{m}^{2}\right)$, and the average pollution loads of TSS, $\mathrm{BOD}_{5}$, and $\mathrm{F}^{-}$in the green roof runoff were also significantly lower than those in the dry and wet deposition. However, the average pollutant loads $\mathrm{NO}_{3}{ }^{-}-\mathrm{N}, \mathrm{K}^{+}$, and $\mathrm{Si}^{4+}$, respectively) in the green roof runoff were significantly higher than those in the asphalt roof runoff, dry and wet deposition and rainwater, and the average pollutant load of TOC $\left(438.06 \mathrm{mg} / \mathrm{m}^{2}\right)$ in the green roof runoff were significantly higher than those in the dry and wet deposition $\left(141.78 \mathrm{mg} / \mathrm{m}^{2}\right)$ and rainfall $\left(51.22 \mathrm{mg} / \mathrm{m}^{2}\right)$. There were no significant differences in average $\mathrm{TN}, \mathrm{Cl}^{-}, \mathrm{SO}_{4}{ }^{2-}, \mathrm{DPb}$, $\mathrm{DCu}, \mathrm{DMn}, \mathrm{DFe}$, and DZn pollutant loads between the green roof runoff, asphalt roof runoff, dry and wet deposition, and rainwater. There were no significant differences in $\mathrm{Ca}^{2+}$ and DAl pollution loads between the green roof runoff, asphalt roof runoff and dry

Table 4

Comparison of the mean concentration of water quality parameters for green roof, asphalt roof, rainwater and dry and wet deposition.

\begin{tabular}{|c|c|c|c|c|}
\hline Parameters & Green roof & Asphalt roof & Dry and wet deposition & Rainfall \\
\hline $\mathrm{pH}$ & $6.84 \pm 0.38^{\mathrm{b}}$ & $7.35 \pm 0.31^{\mathrm{a}}$ & $5.98 \pm 0.93^{b c}$ & $5.62 \pm 1.05^{c}$ \\
\hline TSS (mg/L) & $20.42 \pm 14.53^{b c}$ & $67.04 \pm 44.15^{\mathrm{a}}$ & $36.53 \pm 22.66^{\mathrm{ab}}$ & $9.46 \pm 7.69^{c}$ \\
\hline $\mathrm{TP}(\mathrm{mg} / \mathrm{L})$ & $0.113 \pm 0.042^{\mathrm{a}}$ & $0.091 \pm 0.043^{\mathrm{a}}$ & $0.076 \pm 0.094^{\mathrm{ab}}$ & $0.035 \pm 0.022^{\mathrm{b}}$ \\
\hline $\mathrm{TN}(\mathrm{mg} / \mathrm{L})$ & $18.26 \pm 10.95^{\mathrm{a}}$ & $3.03 \pm 1.43^{\mathrm{b}}$ & $3.26 \pm 1.97^{b}$ & $2.63 \pm 1.47^{b}$ \\
\hline $\mathrm{NH}_{4}^{+}-\mathrm{N}(\mathrm{mg} / \mathrm{L})$ & $4.43 \pm 4.41^{\mathrm{a}}$ & $2.00 \pm 1.09^{b}$ & $1.91 \pm 0.77^{\mathrm{b}}$ & $2.22 \pm 0.87^{b}$ \\
\hline $\mathrm{NO}_{3}{ }^{-}-\mathrm{N}(\mathrm{mg} / \mathrm{L})$ & $12.16 \pm 8.23^{\mathrm{a}}$ & $1.02 \pm 0.72^{\mathrm{b}}$ & $1.02 \pm 0.60^{\mathrm{b}}$ & $0.77 \pm 0.52^{\mathrm{b}}$ \\
\hline $\mathrm{BOD}_{5}(\mathrm{mg} / \mathrm{L})$ & $11.05 \pm 11.43^{\mathrm{a}}$ & $4.88 \pm 3.46^{\mathrm{b}}$ & $4.44 \pm 2.99^{b}$ & $2.55 \pm 1.13^{\mathrm{b}}$ \\
\hline $\operatorname{COD}(\mathrm{mg} / \mathrm{L})$ & $230.63 \pm 177.58^{a}$ & $105.25 \pm 52.16^{b}$ & $52.62 \pm 39.05^{\mathrm{bc}}$ & $42.73 \pm 23.01^{c}$ \\
\hline $\mathrm{TOC}(\mathrm{mg} / \mathrm{L})$ & $60.31 \pm 50.17^{a}$ & $16.16 \pm 15.91^{b}$ & $6.09 \pm 4.24^{\mathrm{b}}$ & $2.55 \pm 1.67^{\mathrm{b}}$ \\
\hline $\mathrm{K}^{+}(\mathrm{mg} / \mathrm{L})$ & $11.25 \pm 12.10^{\mathrm{a}}$ & $0.405 \pm 0.353^{b}$ & $0.299 \pm 0.297^{b}$ & $0.196 \pm 0.088^{b}$ \\
\hline $\mathrm{Ca}^{2+}(\mathrm{mg} / \mathrm{L})$ & $37.26 \pm 0.93^{\mathrm{a}}$ & $14.94 \pm 10.97^{b}$ & $7.79 \pm 8.33^{\mathrm{ac}}$ & $4.27 \pm 3.21^{c}$ \\
\hline $\mathrm{Si}^{4+}(\mathrm{mg} / \mathrm{L})$ & $17.43 \pm 8.87^{\mathrm{a}}$ & $2.48 \pm 1.88^{\mathrm{b}}$ & $1.45 \pm 1.29^{\mathrm{b}}$ & $0.949 \pm 0.612^{\mathrm{b}}$ \\
\hline $\mathrm{F}^{-}(\mathrm{mg} / \mathrm{L})$ & $0.931 \pm 1.264^{\mathrm{a}}$ & $0.352 \pm 0.235^{\mathrm{b}}$ & $0.350 \pm 0.188^{b}$ & $0.256 \pm 0.138^{\mathrm{b}}$ \\
\hline $\mathrm{Cl}^{-}(\mathrm{mg} / \mathrm{L})$ & $20.78 \pm 20.04^{a}$ & $4.65 \pm 2.07^{b}$ & $3.35 \pm 1.49^{\mathrm{b}}$ & $3.29 \pm 1.65^{\mathrm{b}}$ \\
\hline $\mathrm{SO}_{4}{ }^{2-}(\mathrm{mg} / \mathrm{L})$ & $51.82 \pm 30.58^{\mathrm{a}}$ & $15.38 \pm 9.58^{\mathrm{b}}$ & $13.56 \pm 7.46^{\mathrm{b}}$ & $9.90 \pm 6.76^{\mathrm{b}}$ \\
\hline $\mathrm{DPb}(\mu \mathrm{g} / \mathrm{L})$ & $17.26 \pm 13.90^{\mathrm{a}}$ & $5.15 \pm 4.06^{\mathrm{b}}$ & $5.42 \pm 5.39^{\mathrm{b}}$ & $6.58 \pm 6.52^{\mathrm{b}}$ \\
\hline $\mathrm{DCu}(\mu \mathrm{g} / \mathrm{L})$ & $13.02 \pm 10.27^{a}$ & $4.80 \pm 3.88^{\mathrm{a}}$ & $18.58 \pm 36.60^{\mathrm{a}}$ & $4.93 \pm 7.48^{\mathrm{a}}$ \\
\hline $\mathrm{DZn}(\mu \mathrm{g} / \mathrm{L})$ & $52.28 \pm 62.33^{\mathrm{a}}$ & $18.88 \pm 17.25^{\mathrm{a}}$ & $28.11 \pm 19.48^{a}$ & $28.64 \pm 23.84^{\mathrm{a}}$ \\
\hline $\operatorname{DAl}(\mu \mathrm{g} / \mathrm{L})$ & $627.40 \pm 674.71^{\mathrm{a}}$ & $84.96 \pm 53.41^{b}$ & $69.65 \pm 52.50^{\mathrm{b}}$ & $52.41 \pm 30.98^{\mathrm{b}}$ \\
\hline $\operatorname{DMn}(\mu \mathrm{g} / \mathrm{L})$ & $55.81 \pm 55.01^{\mathrm{a}}$ & $19.06 \pm 19.25^{b}$ & $27.10 \pm 17.25^{b}$ & $25.41 \pm 18.94^{b}$ \\
\hline $\mathrm{DFe}(\mu \mathrm{g} / \mathrm{L})$ & $673.13 \pm 823.86^{\mathrm{a}}$ & $76.09 \pm 59.95^{b}$ & $62.24 \pm 22.80^{\mathrm{b}}$ & $67.79 \pm 27.39^{b}$ \\
\hline
\end{tabular}

${ }^{*}$ The values refer to means \pm S.D. The values followed by different letter within a row for each kind of roof designate significantly different at $P<0.05$ level by nonparametric Kruskall-Wallis test and Mann-Whitney $U$ test. 

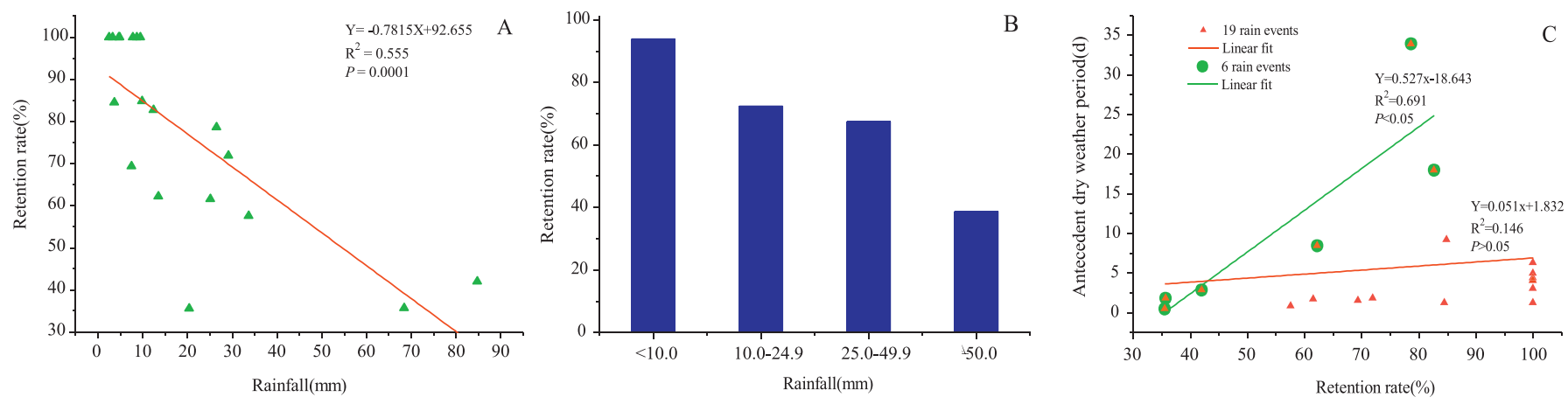

Fig. 3. The relationships between runoff retention and rainfall (A, B) and between antecedent dry weather period (ADWP) and retention rate (C).

and wet deposition; however, the average $\mathrm{Ca}^{2+}$ and DAl pollutant loads were significantly higher in the green roof runoff $(365.00$ and $\left.3.652 \mathrm{mg} / \mathrm{m}^{2}\right)$ than in the rainwater $\left(64.13\right.$ and $\left.1.191 \mathrm{mg} / \mathrm{m}^{2}\right)$.

\section{Discussion}

\subsection{Factors affecting retention capacity of green roofs}

Factors affecting the retention capacity of green roofs include their characteristics (e.g. soil thickness and type, number of layers and type of materials, vegetation cover, and the age, geometry, position and slope/length of the roof) and weather conditions (e.g. rainfall volume, antecedent dry weather period (ADWP), air temperature, wind conditions, humidity, rainfall intensity and rainfall duration) (Berndtsson, 2010).

\subsubsection{Individual components of green roofs}

The substrate depth is an important factor that affect the retention capacity of green roofs. Previous researchs found that the average retention rate of green roof (soil depth $102 \mathrm{~mm}$ ) in Connecticut, USA was 51.4\% (Gregoire \& Clausen, 2011). Stovin (2009) also reported that the average retention rate of a green roof (soil depth $80 \mathrm{~mm}$ ) in Sheffield, UK was 34\%. Hathaway, Hunt, and Jennings (2008), monitoring two green roofs (soil depth 75 and $100 \mathrm{~mm}$ ), found that each green roof retained $64 \%$ of the total precipitation recorded in North Carolina, USA. In our study, the retention rate was greater than that reported by any previous study, which may be due to our use of a deeper soil layer $(150 \mathrm{~mm})$. This is consistent with the findings of VanWoert et al. (2005), who reported that shallower substrate depths and steeper roof slopes resulted in greater runoff from the green roof, and Mentens et al. (2006), who found a significantly negative correlation between the depth of the substrate layer and the annual runoff retention rate.

The species of plants was an important factors affecting retention capacity of green roofs (Nagase \& Dunnett, 2012). Previous research found that plants (Sedum) contribute as much as $40 \%$ of the roof capacity to retain stormwater depending on the frequency and intensity of the storm events (Berghage et al., 2007). In our study, the retention rate was greater than that reported by any previous study, which may be relating with our choosed plant (Sedum buddhanail) due to its larger evaporation intensity.

In addition, water absorption/storage potential of green roof substrate, drainage layer and filter fabric also are important factors affecting the retention capacity of green roofs. More detailed study for these factors need to be carried out in the future work.

\subsubsection{Weather characteristics}

Generally, rainfall volume is the most important weather factor that determines the retention capacity of green roofs. In our study, the depths of rainfall and the runoff retention rates were shown a significant negative relationship $(P<0.01)$ (Fig. 3 A) except the unusual rainfall event on October 12, 2011 (the ADWP was only 0.46 days). As shown on Fig. $3 \mathrm{~B}$, the roof retained nearly $94 \%$ of rainwater from small rainfall events $(<10.0 \mathrm{~mm}),>72 \%$ from medium rainfall events $(10-24.9 \mathrm{~mm})$, $>67 \%$ from large rainfall events (25.0-49.9 mm), and nearly $39 \%$ from storm events $(>50 \mathrm{~mm})$. These results were similar to those obtained by Carter and Rasmussen (2006) in Athens, Georgia, where they found that an inverse relationship existed between the depth of rainfall and the percentage of that rainfall that was retained; for small storms ( $<25.4 \mathrm{~mm}), 88 \%$ was retained; for medium storms $(25.4-76.2 \mathrm{~mm})$, $>54 \%$ was retained; and for large storms $(>76.2 \mathrm{~mm}), 48 \%$ was retained. In addition, the lowest retention rates were occurred in June and October, which may be due to the amount of rainfall being greater in June and October. These results are similar to those obtained by Hathaway et al. (2008) in North Carolina, USA, where they reported that the variations in the monthly percentage rainfall retention were dependent upon the amount of rainfall for each respective month and on the monthly rainfall patterns.

The ADWP is also an important weather factors determining the retention capacity of green roofs. The longer ADWP, the more adequate time to recover the retention capacity of green roofs. As shown Fig. 3C, when considering all the rainfall events (19 rain events), there was no correlation between the runoff retention and $\operatorname{ADWP}(P>0.05)$. When excluding abnormal rainfall events (including the rainfall volume $<10 \mathrm{~mm}$ and rainfall volume is great but short ADWP), there was a significant positive correlation between the retention rate and $\operatorname{ADWP}\left(R^{2}=0.691, P<0.05\right)$. In this study, the green roof retained $100 \%$ of the precipitation for most of the rain events with precipitation depths $<10 \mathrm{~mm}$, except the rain events on July 13, 2011 (69.3\%) and November 7, 2011 (84.5\%), which may be due to the ADWP being shorter, thus giving the soil insufficient time to dry, and therefore meaning that the water-holding capacity of the medium was not fully restored (Hathaway et al., 2008). It is interesting that the smallest retention did not occur during the event with the maximum rainfall, but rather in the rainfall event (October 12, 2011) with an ADWP of only 0.46 days and rainfall of $20.4 \mathrm{~mm}$. Therefore, it appears that the occurrence of an ADWP is a key factor influencing the retention capacity of a green roof (Stovin, 2009).

The higher temperature can lead to the higher rate of evapotranspiration, therefore, the higher the retention capacity of green roofs was generated. In our study, the retention rates in May were lower than in July, August, and September because the higher temperature in these three months results in higher rates of evapotranspiration (Villarreal, 2007), therefore, the waterretaining capacity of the green roof regenerates faster than in the other months. Villarreal, Semadeni-Davies, and Bengtsson (2004) also found that the retention rates of green roofs were higher in warm seasons than in cool and cold seasons. 
Table 5

Pollutants of which green roofs behave as source or sink when compared with rainwater, asphalt roof and dry and wet deposition.

\begin{tabular}{|c|c|c|c|}
\hline Green roof & Rainfall & Dry and wet deposition & Asphalt roof \\
\hline Source & $\mathrm{NO}_{3}{ }^{-}-\mathrm{N}, \mathrm{K}^{+}, \mathrm{Si}^{4+}, \mathrm{Ca}^{2+}, \mathrm{TOC}$ and DAl & $\mathrm{NO}_{3}{ }^{-}-\mathrm{N}, \mathrm{K}^{+}, \mathrm{Si}^{4+}$ and $\mathrm{TOC}$ & $\mathrm{NO}_{3}{ }^{-}-\mathrm{N}, \mathrm{K}^{+}, \mathrm{Si}^{4+}$ and $\mathrm{TOC}$ \\
\hline Sink & $\mathrm{NH}_{4}^{+}-\mathrm{N}$ & $\mathrm{NH}_{4}^{+}-\mathrm{N}, \mathrm{TSS}$ and $\mathrm{F}^{-}$ & $\mathrm{NH}_{4}{ }^{+}-\mathrm{N}, \mathrm{TSS}, \mathrm{BOD}_{5}$ and $\mathrm{F}^{-}$ \\
\hline
\end{tabular}

\subsection{Effect of green roofs on stormwater quality}

Green roofs are being promoted often due to their potential for providing environmental benefits, however, generally little attention is paid to the quality of runoff water (Berndtsson, 2010).

\subsubsection{Pollutants whose concentrations were reduced in green roof runoff}

Chongqing is a typical area of acid rain in China. In our study, the mean $\mathrm{pH}$ of rainfall is 5.61 , beyond the standard range (6.0-9.0) of surface water. However, the $\mathrm{pH}$ value increased when the rainwater flowed through the green roof and reached the mean value of 6.84 (within the standard range), which is an important function that help to reduce the acidity of natural water input. Therefore, the green roof can neutralize the local rainwater. These results are consistent with those obtained by Berndtsson, Bengtsson, and Jinno (2009) in their study of intensive vegetated roofs in Japan, and by Teemusk and Mander (2007) in their study of green roofs in Estonia.

Our results showed that the green roof reduced the concentration of TSS in stormwater runoff, because one explanation for this effect is that the growing medium and filter layers of the green roof prevent particles going into the runoff. Mendez et al. (2011) found that the TSS of the rainwater harvested after the first flush was lower for a green roof than those for an asphalt fiberglass shingle roof, concrete tile roof, and metal roof $(P<0.047)$.

\subsubsection{Pollutants whose concentrations were increased in green roof runoff}

In our study, the green roof increased the concentrations of TN, $\mathrm{NH}_{4}{ }^{+}-\mathrm{N}, \mathrm{NO}_{3}{ }^{-}-\mathrm{N}$ in stormwater runoff. The higher nutrients concentrations of the green roof may indicate that the $\mathrm{TN}, \mathrm{NH}_{4}{ }^{+}-\mathrm{N}$, and $\mathrm{NO}_{3}{ }^{-}-\mathrm{N}$ were released from the roof substrate. Beecham and Razzaghmanesh (2015) found that green roofs generally acted as sources of pollutants. Moran, Hunt, and Smith (2005) observed substantial release of TN from green roofs. Teemusk and Mander (2007) also found that green roofs released more $\mathrm{NH}_{4}{ }^{+}-\mathrm{N}$ after heavy rainstorms and snowmelt, and that the $\mathrm{NO}_{3}{ }^{-}-\mathrm{N}$ content was higher in the runoff water in all cases, which was probably due to the influence of the plants and the substrate layer. Concentrations of nitrogen in green roof runoff can be linked to the type of soil, age of green roof and maintenance of the roof (e.g. use of fertilizers) (Berndtsson, 2010). In our study, the green roof was not being fertilized; however, we chose a substrate (soil mix consisting of $40 \%$ peat soil, $30 \%$ vermiculite, $20 \%$ perlite, and $10 \%$ sawdust) that was high in nitrogen (Zhang et al., 2014), therefore, we believe that the higher concentrations of $\mathrm{TN}, \mathrm{NH}_{4}{ }^{+}-\mathrm{N}$ and $\mathrm{NO}_{3}{ }^{-}-\mathrm{N}$ originated mainly from the substrate layer.

The green roof also increased the concentrations of TOC and COD in stormwater runoff. The elevated TOC and COD concentrations observed in the green roof runoff originated from the organic matter in the soil and the decaying vegetation. Berndtsson et al. (2009) observed that the source of DOC was the organic material from the roof soil and the carbon originating from the decomposition of vegetation. Mason, Ammann, Ulrich, and Sigg (1999) found that the roof runoff infiltration through soil showed that a major part of DOC behaved conservatively during infiltration. Bliss, Neufeld, and Ries (2009) showed the COD in green roof runoff was also greater than in samples from the control (conventional ballasted membrane roof) roof. In our study, the average COD from asphalt roof was significantly higher than that in the dry and wet deposition and rain water and the average TOC from the asphalt roof was also relatively high. One explanation for this effect is that certain roofing materials are likely to be sources of TOC and COD. Mendez et al. (2011) found that an asphalt fiberglass shingle roof was a source of organic matter. Drapper, Tomlinson, and Williams (2000) found that the TOC and COD concentrations in asphalt road were 3-5 times higher than that of in runoff from a concrete road.

The green roof increased the concentration of anions $\left(\mathrm{F}^{-}, \mathrm{Cl}^{-}\right.$, and $\mathrm{SO}_{4}{ }^{2-}$ ) and cations $\left(\mathrm{K}^{+}, \mathrm{Ca}^{2+}\right.$, and $\left.\mathrm{Si}^{4+}\right)$, probably derived from the substrate materials. Such effects were also noted by Vijayaraghavan et al. (2012) and Berndtsson et al. (2009).

The source of the DPb, DAl, DMn, and DFe found from the green roofs was probably the substrate. In our study, the substrate layer (soil mix consisting of $40 \%$ peat soil, $30 \%$ vermiculite, $20 \%$ perlite, and $10 \%$ sawdust) contained large amounts of metals ( $\mathrm{Al}, \mathrm{Mn}$, and $\mathrm{Fe}$ ), thus a substantial release of DPb, DAl, DMn, and DFe from the studied green roofs would not be unexpected. Such effects were also noted by Vijayaraghavan et al. (2012) and Mendez et al. (2011).

It is noteworthy that the green roof did not significantly increase the concentration of TP in stormwater. One explanation may be that the TP mainly originates from dry and wet deposition. Berndtsson et al. (2006, 2009) found that green roofs did not release any phosphorus. Monterusso, Rowe, Rugh, and Russell (2002) and Moran et al. (2005) also found that the addition of fertilizer to green roofs was a common source of phosphorus. In our study, we did no apply any fertilizer to the green roof, thus we believe that the TP mainly originated from dry and wet deposition.

\subsection{Green roofs behave as pollutant sinks or sources}

Because the green roof has a good retention capacity, the pollutant loads in green roof runoff might be reduced. Therefore, it is unscientific that determine the characteristics of green roofs behave as a "sink" or a "source" in terms of only the quality of runoff water. In our study, compared with the rainwater, the green roof significantly reduced the pollution load of $\mathrm{NH}_{4}{ }^{+}-\mathrm{N}$, therefore, it seems that the green roof was a sink for this pollutant. However, the green roof was the source of the $\mathrm{NO}_{3}{ }^{-}-\mathrm{N}, \mathrm{K}^{+}, \mathrm{Si}^{4+}, \mathrm{Ca}^{2+}$, TOC and DAl due to the green roofs significantly increasing their pollutant loads. Pollutants of which green roofs behave as sinks and sources vary when their pollutant loads are compared with asphalt (control) roof and dry and wet deposition (Table 5).

\subsection{Future line of research for green roofs}

Generally, the green roof was as an effective measure of reducing roof pollutant load. However, little attention is paid to the quality of runoff water. Therefore, the stormwater runoff of green roofs could be a source of water body pollution. In this study, it was found that some pollutants in runoff were mainly from the substrate components of green roofs. Therefore, future work should start from screening and optimizing the substrates of green roof, and added some materials that can purify runoff quality, such as biochar and $\mathrm{Fe}^{0}$, etc., so that it can meet the necessary nutrients for plants growth, and also have little impact on the quality of runoff water. Although researchers have carried out lots of studies on factors affecting the effect of the runoff intercepting and pollution reducing, the interaction among the influencing factors resulting 
in the mechanism of the runoff intercepting and pollution reducing has less been explored. Therefore, further study is needed for a long time in order to applying and promoting the technology of controlling non-point pollution of green roof.

\section{Conclusion}

The present study investigated the runoff water quality and runoff retention of green roofs based on 19 rainfall events. The water quality parameters of $\mathrm{pH}, \mathrm{BOD}_{5}, \mathrm{COD}, \mathrm{NH}_{4}^{+}-\mathrm{N}, \mathrm{NO}_{3}{ }^{-}-\mathrm{N}, \mathrm{TP}$, TN, TOC, TSS, $\mathrm{K}^{+}, \mathrm{Ca}^{2+}, \mathrm{Si}^{4+}, \mathrm{F}^{-}, \mathrm{Cl}^{-}, \mathrm{SO}_{4}{ }^{2-}$, DPb, DCu, DZn DFe, DAl, and DMn were measured for green roof runoff, asphalt roof (control roof) runoff, dry and wet deposition, and rainfall samples in order to identify the pollutant source and sink of green roof. The following conclusions were drawn:

Examining these rainfall events, we found that the retention rate ranged from $35.5 \%$ to $100 \%$, with an average retention rate of $77.2 \%$. The retention rate varied with the rainfall intensity, with retention of nearly $94 \%$ for small rainfall events $(<10.0 \mathrm{~mm}),>72 \%$ for medium rainfall events $(10.0-24.9 \mathrm{~mm}),>67 \%$ for large rainfall events (25.0-49.9 mm) and nearly $39 \%$ for storm events (>50 mm). There were significant negative relationships between the runoff retention rate and the depth of the rainfall $(P<0.01)$.

The monthly runoff retention rates of the green roof were smaller in June and October than in July, August, and September, because of the larger amount of rainfall in June and October and the higher temperature in July, August, and September. The annual runoff retention volume and retention rates of the green roof were $758.7 \mathrm{~mm}$ and $68.0 \%$, respectively.

When we compared the stromwater quality among the green roof, asphalt (control) roof, dry and wet deposition and rainfall samples, found that the green roof reduced the concentration of TSS, and could neutralize the $\mathrm{pH}$ of rainfall; however, it increased the concentrations of $\mathrm{TN}, \mathrm{NH}_{4}{ }^{+}-\mathrm{N}, \mathrm{NO}_{3}{ }^{-}-\mathrm{N}, \mathrm{TOC}, \mathrm{COD}, \mathrm{BOD}_{5}, \mathrm{~F}^{-}$, $\mathrm{Cl}^{-}, \mathrm{SO}_{4}{ }^{2-}, \mathrm{K}^{+}, \mathrm{Ca}^{2+}, \mathrm{Si}^{4+}, \mathrm{DPb}, \mathrm{DAl}, \mathrm{DMn}$, and DFe. When we compared the pollutant loads from the green roof and rainfall samples, found that the green roof was a sink for $\mathrm{NH}_{4}{ }^{+}-\mathrm{N}$, but, was sources of $\mathrm{NO}_{3}{ }^{-}-\mathrm{N}, \mathrm{K}^{+}, \mathrm{Si}^{4+}, \mathrm{Ca}^{2+}$, TOC and DAl.

In conclusion, the runoff water quality from the green roof was significantly affected by the composition of the soil layer, and the runoff retention rate of the green roof was significantly affected by the depth of the soil layer and the intensity of the rainfall. Therefore, selection of green roof medium is an important part of the design standards for green roof. We did not examine other parameters such as microbial pathogens and pesticides, and the runoff peak delays were not researched, thus, further investigations will be necessary to research these parameters and the runoff peak delays.

\section{Acknowledgements}

The study was funded by the National Natural Science Foundation of China (No. 41401593 and No. 41230633) and the open funds of State Key Laboratory of Urban and Region Ecology of China (No. SKLURE2015-2-3) and the National Water Pollution Control and Management Technology major projects of China (No. 2012ZX07307).

\section{References}

Beecham, S., \& Razzaghmanesh, M. (2015). Water quality and quantity investigation of green roofs in a dry climate. Water Research, 70, 370-384.

Berardi, U., GhaffarianHoseini, A., \& GhaffarianHoseini, A. (2014). State-of-the-art analysis of the environmental benefits of green roofs. Applied Energy, 115, 411-428.

Berghage, R., Jarrett, A., Beattie, D., Kelley, K., Husain, S., Rezai, F., et al. (2007) Quantifying evaporation and transpirational water losses from green roofs and green roof media capacity for neutralizing acid rain. Report, National
Decentralized Water Resources (NDWRCP) Research Project, Pennsylvania State University.

Berndtsson, J. C. (2010). Green roof performance towards management of runoff water quantity and quality: A review. Ecological Engineering, 36(4), 351-360.

Berndtsson, J. C., Emilsson, T., \& Bengtsson, L. (2006). The influence of extensive vegetated roofs on runoff water quality. Science of the Total Environment, 355(1), 48-63.

Berndtsson, J. C., Bengtsson, L., \& Jinno, K. (2008). First flush effect from vegetated roofs during simulated rain events. Hydrology Research, 39(3), 171-179.

Berndtsson, J. C., Bengtsson, L., \& Jinno, K. (2009). Runoff water quality from intensive and extensive vegetated roofs. Ecological Engineering, 35(3), 369-380.

Bliss, D. J., Neufeld, R. D., \& Ries, R. J. (2009). Storm water runoff mitigation using a green roof. Environmental Engineering Science, 26(2), 407-418.

Beijing Local Standards (BLS). (2005). Code for roof greening. Beijing: Beijing Municipal Administration of Quality and Technology Supervision (in Chinese).

Carter, T. L., \& Rasmussen, T. C. (2006). Hydrologic behavior of vegetated roof S1. Journal of the American Water Resources Association, 42(5), 1261-1274.

Chen, C. F. (2013). Performance evaluation and development strategies for green roofs in Taiwan: A review. Ecological Engineering, 52, 51-58.

Currie, B. A., \& Bass, B. (2008). Estimates of air pollution mitigation with green plants and green roofs using the UFORE model. Urban Ecosystems, 11(4), 409-422.

Drapper, D., Tomlinson, R., \& Williams, P. (2000). Pollutant concentrations in road runoff: Southeast Queensland case study. Journal of Environmental Engineering, 126(4), 313-320.

Dunnett, N., Nagase, A., \& Hallam, A. (2008). The dynamics of planted and colonising species on a green roof over six growing seasons 2001-2006: Influence of substrate depth. Urban Ecosystems, 11(4), 373-384.

Fang, C. F. (2008). Evaluating the thermal reduction effect of plant layers on rooftops. Energy and Buildings, 40(6), 1048-1052.

Gedge, D., \& Kadas, G. (2005). Green roofs and biodiversity. Biologist, 52(3), 161-169.

Getter, K. L., Rowe, D. B., \& Andresen, J. A. (2007). Quantifying the effect of slope on extensive green roof stormwater retention. Ecological Engineering, 31(4), 225-231.

Gregoire, B. G., \& Clausen, J. C. (2011). Effect of a modular extensive green roof on stormwater runoff and water quality. Ecological Engineering, 37(6), 963-969.

Hathaway, A., Hunt, W. F., \& Jennings, G. (2008). A field study of green roof hydrologic and water quality performance. Transactions of the American Society of Agricultural and Biological Engineers, 51(1), 37-43.

Lee, J., Moon, H., Kim, T., Kim, H., \& Han, M. (2013). Quantitative analysis on the urban flood mitigation effect by the extensive green roof system. Environmental Pollution, 181, 257-261.

Lee, J. Y., Lee, M. J., \& Han, M. (2015). A pilot study to evaluate runoff quantity from green roofs. Journal of Environmental Management, 152, 171-176.

Mason, Y., Ammann, A. A., Ulrich, A., \& Sigg, L. (1999). Behavior of heavy metals, nutrients, and major components during roof runoff infiltration. Environmental Science \& Technology, 33(10), 1588-1597.

Mendez, C. B., Klenzendorf, J. B., Afshar, B. R., Simmons, M. T., Barrett, M. E., Kinney, K. A., et al. (2011). The effect of roofing material on the quality of harvested rainwater. Water Research, 45(5), 2049-2059.

Mentens, J., Raes, D., \& Hermy, M. (2006). Green roofs as a tool for solving the rainwater runoff problem in the urbanized 21st century? Landscape and Urban Planning, 77(3), 217-226.

Monterusso, M., Rowe, D., Rugh, C., \& Russell, D. (2002). Runoff water quantity and quality from green roof systems. In XXVI International Horticultural Congress: Expanding Roles for Horticulture in Improving Human Well-Being and Life Quality, vol. 639 (pp. 369-376)

Moran, A. C., Hunt, B., \& Jennings, G. (2004). A North Carolina field study to evaluate greenroof runoff quantity, runoff quality, and plant growth. North Carolina State University.

Moran, A., Hunt, B., \& Smith, J. (2005). Hydrologic and water quality performance from greenroofs in Goldsboro and Raleigh, North Carolina. In Third Annual Greening Rooftops for Sustainable Communities Conference, Awards and Trade Show (pp. 4-6).

Nagase, A., \& Dunnett, N. (2012). Amount of water runoff from different vegetation types on extensive green roofs: Effects of plant species, diversity and plant structure. Landscape and Urban Planning, 104, 356-363.

Sazakli, E., Alexopoulos, A., \& Leotsinidis, M. (2007). Rainwater harvesting, quality assessment and utilization in Kefalonia Island, Greece. Water Research, 2007(41), 2039-2047.

State Environment Protection Agency of China (SEPAC). (2002a). Methods of monitoring and analysis for water and wastewater (4th ed.). Beijing: China Environmental Science Press (in Chinese).

State Environment Protection Agency of China (SEPAC). (2002b). Environmental quality standards for surface water (GB3838-2002). Beijing: China Environmental Science Press (in Chinese).

Stovin, V. (2009). The potential of green roofs to manage urban stormwater. Water and Environment Journal, 24(3), 192-199.

Stovin, V., Dunnett, N., \& Hallam, A. (2007). Green roofs - getting sustainable drainage off the ground. In 6th International Conference of Sustainable Techniques and Strategies in Urban Water Management (Novatech 2007) Lyon, France, (pp. 11-18). 
Teemusk, A., \& Mander, Ü. (2007). Rainwater runoff quantity and quality performance from a greenroof: The effects of short-term events. Ecological Engineering, 30(3), 271-277.

VanWoert, N. D., Rowe, D. B., Andresen, J. A., Rugh, C. L., Fernandez, R. T., \& Xiao, L. (2005). Green roof stormwater retention. Journal of Environmental Quality, 34(3), 1036-1044.

Vijayaraghavan, K., \& Raja, F. D. (2015). Pilot-scale evaluation of green roofs with Sargassum biomass as an additive to improve runoff quality. Ecological Engineering, 75, 70-78.

Vijayaraghavan, K., Joshi, U., \& Balasubramanian, R. (2012). A field study to evaluate runoff quality from green roofs. Water Research, 46(4), 1337-1345.

Villarreal, E. L. (2007). Runoff detention effect of a sedum green-roof. Nordic Hydrology, 38(1), 99-105.
Villarreal, E. L., \& Bengtsson, L. (2005). Response of a Sedum green-roof to individual rain events. Ecological Engineering, 25(1), 1-7.

Villarreal, E. L., Semadeni-Davies, A., \& Bengtsson, L. (2004). Inner city stormwater control using a combination of best management practices. Ecological Engineering, 22(4), 279-298.

Wong, N. H., Chen, Y., Ong, C. L., \& Sia, A. (2003). Investigation of thermal benefits of rooftop garden in the tropical environment. Building and Environment, 38(2), 261-270.

Zhang, Q. Q., Wang, X. K., Hou, P. Q., Wan, W. X., Li, R. D., Ren, Y. F., et al. (2014). Quality and seasonal variation of rainwater harvested from concrete, asphalt, ceramic tile and greening roofs in Chongqing, China. Journal of Environmental Management, 132, 178-187. 